\title{
It is all about power: Corruption, patriarchy and the political participation of women
}

Citation for published version (APA):

Merkle, O., \& Wong, P. H. (2020). It is all about power: Corruption, patriarchy and the political participation of women. In Women and Sustainable Human Development: Empowering Women in Africa (pp. 353-368). Palgrave Macmillan. https://doi.org/10.1007/978-3-030-14935-2_20

Document status and date:

Published: 01/01/2020

DOI:

https://doi.org/10.1007/978-3-030-14935-2_20

Document Version:

Publisher's PDF, also known as Version of record

Document license:

Taverne

Please check the document version of this publication:

- A submitted manuscript is the version of the article upon submission and before peer-review. There can be important differences between the submitted version and the official published version of record.

People interested in the research are advised to contact the author for the final version of the publication, or visit the DOI to the publisher's website.

- The final author version and the galley proof are versions of the publication after peer review.

- The final published version features the final layout of the paper including the volume, issue and page numbers.

Link to publication

\footnotetext{
General rights rights.

- You may freely distribute the URL identifying the publication in the public portal. please follow below link for the End User Agreement:

www.umlib.nl/taverne-license

Take down policy

If you believe that this document breaches copyright please contact us at:

repository@maastrichtuniversity.nl

providing details and we will investigate your claim.
}

Copyright and moral rights for the publications made accessible in the public portal are retained by the authors and/or other copyright owners and it is a condition of accessing publications that users recognise and abide by the legal requirements associated with these

- Users may download and print one copy of any publication from the public portal for the purpose of private study or research.

- You may not further distribute the material or use it for any profit-making activity or commercial gain

If the publication is distributed under the terms of Article $25 \mathrm{fa}$ of the Dutch Copyright Act, indicated by the "Taverne" license above, 


\title{
It Is All about Power: Corruption, Patriarchy and the Political Participation of Women
}

\author{
Ortrun Merkle and Pui-Hang Wong
}

\section{INTRODUCTION}

With the 1995 Beijing Declaration and Platform for Action, the Millennium Development Goals (Goal 3) and the Sustainable Development Goals (SDGs) (Goal 5), more attention has been paid to gender equality in the international arena. One fundamental aspect of achieving this equality is increasing the level of political participation of women. Within this discourse two seminal studies, Dollar et al. (2001) and Swamy et al. (2001), bring about a new focus: the potential of women in politics as an anti-corruption force. They argue that, on average, women are less likely to engage in corruption than men and that achieving higher rates of political participation of women will decrease levels of corruption in society. This argument, also known as the "fairer-sex hypothesis", was quickly picked up by the World Bank, which identified gender equality as an important tool to curb corrup-

O. Merkle $(\square) \bullet$ P.-H. Wong

United Nations University (UNU-MERIT), Maastricht University, Maastricht, The Netherlands

Maastricht Graduate School of Governance, Maastricht University, Maastricht, The Netherlands

e-mail: merkle@merit.unu.edu; wong@merit.unu.edu

(C) The Author(s) 2020

M. Konte, N. Tirivayi (eds.), Women and Sustainable Human

Development, Gender, Development and Social Change, https://doi.org/10.1007/978-3-030-14935-2_20 
tion (King and Mason 2001). Since then there have been heated debates about the nexus of corruption and gender. One of the most prominent criticisms is that the focus on latent gender differences oversimplifies a complicated relationship and is counterproductive for the fight against corruption and in efforts aimed at increasing women's political participation. However, research that analyses this relationship is limited. This chapter asserts that most of the existing research on corruption and gender simplifies the understanding of gender by focusing solely on women and, only in rare instances, on gender, namely socially constructed roles, activities, attributes, behaviours, personality traits, relationships, power and influence that a society conceptually attributes to men and women (Prince 2005) and gender dynamics.

Gender is an institutionalized "multilevel system of differences and disadvantages that includes socioeconomic arrangements and widely held cultural beliefs at the macro level, ways of behaving in relation to others at the interactional level, and acquired traits and identities at the individual level" (Ridgeway 1997, p. 219). Yet, the discussion on corruption typically treats gender as a one-dimensional variable and neglects the role of underlying dynamics. This chapter addresses this gap by arguing that, in order to understand how corruption (i.e. the abuse of power) works, one must have a better understanding of how power is distributed within society. Therefore, this chapter argues that rather than being a question of inherent gender differences, both the question of acceptance of corruption and that of women's political participation are linked to an underlying patriarchal system. Using a gender-centred theory, such as patriarchy, will deepen the understanding of "the complex ways that gender interacts with other social conditions and processes" (Hunnicutt 2009, p. 556).

This study investigates the correlation between attitudes towards female political leadership and the acceptance of corruption. The study hypothesizes that both corruption and women's political participation are essentially questions of how power is distributed within society and therefore influenced by patriarchic structures. It finds that men and women who agree that men are better political leaders than women are more likely to condone corruption. This suggests that underlying patriarchal norms influence attitudes towards corruption. These findings provide new insights on the relationship between higher political participation of women (SDG target 5.5.) and lower corruption levels (SDG target 16.5). The chapter is organized as follows: Section 2 discusses the theoretical argument while Sect. 3 introduces the data and methodology. A discussion of the findings is presented in Sect. 4, and Sect. 5 concludes the chapter by providing policy recommendations. 


\section{Corruption and Patriarchy as Asymmetric Power Relations}

According to Rothstein and Teorell (2008), a political process can be divided into an input side (access to power) and an output side (exercise of power). Corruption takes place in the exercise of power, as reflected in the majority of corruption definitions, for example, Transparency International (para. 1, n.d.) defines corruption as "the abuse of entrusted power for private gain". Hence, in the corruption literature, the exercise of political power is frequently scrutinized. Surprisingly, even though most definitions refer to corruption as an abuse of power, the existing literature is usually completely detached from the aspect of access to power, and discussions about the dysfunction of the governing process routinely neglect questions about the distribution of power. Some researchers even explicitly exclude these questions. Rothstein (2011) and Rothstein and Teorell (2008), for example, discuss the concept of "quality of government" as the opposite of corruption in terms of impartiality. In their view, the principle of impartiality is upheld when "government officials shall not take into consideration anything about the citizen/case that is not beforehand stipulated in the policy or the law" (Rothstein and Teorell 2008, p. 170). This definition focuses on the question of how authority is exercised without looking at who exercises this authority. While in the ideal case of a perfectly functioning government this can be logical, the definition gets problematic in the instances where officials violate this ideal state.

As feminist research has shown, the argument that one can look at exercise of power independently is a gross oversimplification, and for good reason, the question of who has access to the political system and how access is granted are fundamental debates in political science. Most researchers agree that the underlying principle of how a state should be governed is that of political equality, that is, equal access to political powers for all groups within the state, which is not synonymous with democracy. While democracy certainly does provide the best opportunity for political equality, it is not, by default, a guarantee that all groups are included. For women, democracy has been shown to have a positive effect, but it is not by itself sufficient for equality (i.e. Friedman 2000; Goetz and Hassim 2003; Matland and Montgomery 2003; Waylen 2003).

A state can only have legitimacy if all groups are included in the political process; hence, the political participation of women is a building block of state legitimacy (Thomas 2005). In democracies, both men and women per- 
ceive the government to be more legitimate if a sufficient number of women are represented, since the proper representation of disadvantaged groups indicates that the majority can trust that their interests are properly heard (Schwindt-Bayer and Mishler 2005). In 1861, John Stuart Mill argued that "in the absence of its natural defenders, the interest of the excluded is always in danger of being overlooked; and when looked at, is seen with very different eyes from those of the persons who it directly concerns" (Mill 2015 [1861], p. 216). Importantly, while a small number of women holding political office can already achieve positive outcomes for women, a "critical mass", i.e. a certain number of female politicians seems to be needed to achieve lasting societal impact (Bratton and Ray 2002; Schwindt-Bayer and Mishler 2005, p. 424). This is one of the rationales behind gender quotas, which have become increasingly important to ensure a faster increase in the number of women in parliament (Bauer and Burnet 2013). Yet, this is only useful if attention is also paid to the question of which women are actually joining the political sphere, as power structures within society often grant different access to women with different ethnic, religious, economic and political backgrounds.

Despite the established positive impacts of women's political participation, there are many roadblocks that affect how small the window is for women to be politically engaged. For instance, a woman's decision to seek political office often includes more deliberations about family-related obligations unlike a man's decision. Yet Fulton et al. (2006) argue that women are more aware of the benefits that holding elected office provides and have a deeper sense of responsibility once they do hold the job. Political institutions and culture also can act as obstacles. Many researchers find that electoral systems have an impact on the political participation of women (Matland and Brown 1992; Norris 1985; Rule 1994), as do party size and orientation (Kittilson 2006). The political culture also has a direct effect on how individuals see their representatives and what qualifications and characteristics they expect. Fox and Lawless (2004) point out that the socialization of politics is still biased towards allowing more men to participate in the process, and the paradigm that men are more suited for holding public office remains in place. This paradigmatic thinking has an impact on not only parties' candidate selection but also potential female candidates, who often feel less qualified for public office than men with similar experience and education.

The reasons that women do not (yet) participate enough are centred firmly around sexist stereotypes. While sexism is often understood as hostility against women, many of these sexist stereotypes are not at first 
sight understood as negative and are much subtler. In a seminal study, Glick and Fiske (1996) distinguish two types of sexism: hostile and benevolent. Hostile sexism is prejudice. By contrast, benevolent sexism is associated with positive feelings, which tend to elicit prosocial behaviours such as helping. However, benevolent sexism evokes traditional stereotypes and can be equally damaging; for example, it usually projects the image of the man as the provider and a woman as his dependent, being nice but incompetent at many important tasks (Glick and Fiske 1996). Therefore, both hostile and benevolent sexism are driven by a patriarchal structure, which places women in a subordinate position and creates dependency to consolidate men's structural power and violates the principle of equality. Consequently, patriarchy is not a simplistic concept of "bad" men having power over "poor" women. On the contrary, patriarchy can be understood as a complex system of power relationships where "both men and women wield varying types and amounts of power" (Hunnicutt 2009, p. 565). Patriarchy should also not be seen as a static system; rather, it is a continuously evolving web of ideas and relationships (Enloe 2017, p. 16).

In short, ignoring the power access problem and neglecting the power structure in politics will prevent a deeper understanding of how corruption is embedded in society. Hence, this chapter hypothesizes that both the idea of the importance of equal participation of women and the view on the acceptability of corruption speak to the question of how patriarchy is embedded in the structure of society. Therefore, unlike what the fairersex hypothesis suggests, gender differences-be they inclination to sacrifice personal gains or disparity in self-control-do not explain tolerance towards corruption. Rather, it is underlying patriarchal norms that matter for the persistence of corruption. This chapter is looking at views on women as a representation of the underlying patriarchal structure and tests the following hypothesis: People who agree that men are better politicians than women are more likely to condone corruption.

\section{Data And Methodology}

Data for this chapter come from the latest wave of the World Values Survey (2010-2014) (Inglehart et al. 2014). The World Values Survey database consists of nationally representative surveys conducted in about 100 countries using a common questionnaire. This study only includes surveys for sub-Saharan Africa countries. Countries for which surveys are available are Ghana, Nigeria, Rwanda, South Africa and Zimbabwe. The analytical sample used for the analysis contains 9827 observations from these countries. 
This study investigates the correlation between attitudes towards women's political leadership and attitudes towards corruption. It does not claim causality and only uses regression analysis to identify a pattern, while accounting for various factors. The empirical analysis pools individual responses across the five sub-Saharan Africa countries and includes dummy variables for each country to account for country heterogeneity. The dependent variable is the attitude towards corruption. Respondents were asked to indicate whether they think "[s]omeone accepting a bribe in the course of their duties" is justifiable. Responses are reported on a ten-point Likert scale, where 1 indicates "never justifiable" and 10 "always justifiable". Given the number of possible responses, the variable is treated as an ordered response, since about $80 \%$ of the responses take an extreme value (i.e. scales 1 and 2 ).

The key independent variable denotes the attitudes towards women's political leadership. The measure is derived from a question, which asks respondents to indicate whether they agree with the following statement: "On the whole, men make better political leaders than women do". Responses are reported on a four-point Likert scale, where 1 indicates "strongly agree" and 4 "strongly disagree". Given the small number of possible responses, treating the variable as continuous imposes a strong linearity assumption on the relationship between the dependent and independent variables; that is, the effect of a one-point increase from "strongly agree" to "agree" is the same as the one from "agree" to "disagree". The assumption is likely to be untrue. Therefore, five dummy variables are created and used to avoid making this bold assumption. Each dummy variable corresponds to a scale point, plus an additional one that pools "missing" and "do not know" together. The baseline is "agree" and is omitted in regression models to avoid perfect multicollinearity.

Several control variables are also included in the analysis. The gender of the respondent is controlled for since women and men may respond differently, according to the fairer-sex hypothesis (Dollar et al. 2001). The other control variables include age, marital status, religiosity and employment status (i.e. employed, unemployed, inactive). People who are the chief wage earner of a household and work in a certain sector may have a higher exposure to corruption in their workplace. To account for the potential differences in responses, both variables are included in the regression. Moreover, since the income level of the respondent was not captured in the survey, self-reported class levels are used to proxy the economic well-being of the respondents. Possible responses are "upper class", "upper middle", "upper lower", "working class", "lower class" and “don't 
know". The baseline is "lower class". Education can be a powerful policy tool to combat corruption (Eicher et al. 2009). To control for the effect of education, the variable is included as well. The original survey response has nine categories, ranging from 1 (no formal education) to 9 (universitylevel education, with degree). For simplicity, the education level is coded as a continuous variable. Finally, people who thought that "having a strong leader who does not have to bother with parliament and elections" is a good (or bad) way of governing the country may have a stronger opinion about corruption. A set of five variables is created to control for this effect (very good, fairly good, fairly bad, very bad, don't know). The baseline is "very bad".

Due to the ordinal nature of the dependent variable, an ordered logit model is used in the analysis. Furthermore, a multilevel logistic regression is utilized as a robustness check to accommodate the hierarchical structure of the data. More specifically, in the context of survey data analysis, individuals are usually found to be influenced by a common set of contextual factors; for example, people living in one region are subjected to the same policy. This feature of the data makes responses from the same region correlated. If the correlation is particularly strong, the usual ordered logit model will lead to smaller standard errors and hence inaccurate hypothesistesting results (Steenbergen and Jones 2002). Under this circumstance, a multilevel model might be superior to the usual ordered logit model, as it can explicitly model this kind of dependency and, at the same time, account for unobserved heterogeneity. The model looks similar to the usual ordered logit model, but with a constant containing a random component, which is allowed to vary across region $j$ in which respondent $i$ lived. This random component is assumed to have zero mean and its variance is estimated explicitly.

\section{Findings And Discussion}

Estimation results are reported in Table 20.1. Model (1) includes only the key independent variables and country dummies as covariates. It shows that people who strongly disagreed that men are better political leaders are also less likely to think that corruption is justifiable than those who agree. The estimate is statistically significant at the $1 \%$ level. The findings lend support to the hypothesis that perceptions of corruption and attitudes towards women's political leadership are related to underlying norms, that is, patriarchy. The coefficient of the dummy variable "disagree" is negative 
Table 20.1 Relationship between attitude towards women as political leaders and corruption

\begin{tabular}{|c|c|c|c|}
\hline & (1) & (2) & \multirow{2}{*}{$\frac{\text { (3) }}{M L \text { ordered logit }}$} \\
\hline & Ordered logit & Ordered logit & \\
\hline \multirow[t]{2}{*}{ Men better (don't know) } & $-1.013^{* * *}$ & $-0.764^{* * *}$ & $-0.527^{* *}$ \\
\hline & $(0.082)$ & $(0.067)$ & $(0.186)$ \\
\hline \multirow[t]{2}{*}{ Men better (strongly agree) } & -0.208 & -0.173 & -0.098 \\
\hline & $(0.119)$ & $(0.124)$ & $(0.051)$ \\
\hline Men better (agree) & Baseline & Baseline & Baseline \\
\hline \multirow[t]{2}{*}{ Men better (disagree) } & -0.385 & $-0.364^{*}$ & $-0.373^{* * *}$ \\
\hline & $(0.215)$ & $(0.171)$ & $(0.050)$ \\
\hline \multirow[t]{2}{*}{ Men better (strongly disagree) } & $-0.630^{* *}$ & $-0.501^{*}$ & $-0.468^{\star * *}$ \\
\hline & $(0.238)$ & $(0.209)$ & $(0.070)$ \\
\hline \multirow[t]{2}{*}{ Female } & & 0.027 & 0.034 \\
\hline & & $(0.056)$ & $(0.040)$ \\
\hline \multirow[t]{2}{*}{ Age } & & $-0.008^{\star \star *}$ & $-0.006^{* * *}$ \\
\hline & & $(0.001)$ & $(0.002)$ \\
\hline \multirow[t]{2}{*}{ Education } & & -0.029 & $-0.035^{* *}$ \\
\hline & & $(0.023)$ & $(0.011)$ \\
\hline \multirow[t]{2}{*}{ Religious (Yes = 1) } & & -0.057 & $-0.136^{*}$ \\
\hline & & $(0.062)$ & $(0.066)$ \\
\hline \multirow[t]{2}{*}{ Married } & & $-0.162^{* * *}$ & $-0.144^{* * *}$ \\
\hline & & $(0.042)$ & $(0.043)$ \\
\hline \multirow[t]{2}{*}{ Chief wage earner $($ Yes $=1)$} & & 0.047 & 0.073 \\
\hline & & $(0.057)$ & $(0.047)$ \\
\hline Work (not working) & & Baseline & Baseline \\
\hline \multirow[t]{2}{*}{ Work (government) } & & 0.093 & 0.104 \\
\hline & & $(0.145)$ & $(0.084)$ \\
\hline \multirow{2}{*}{ Work (private sector) } & & 0.021 & -0.002 \\
\hline & & $(0.202)$ & $(0.067)$ \\
\hline \multirow[t]{2}{*}{ Work (non-profit) } & & 0.132 & 0.112 \\
\hline & & $(0.252)$ & $(0.082)$ \\
\hline \multirow[t]{2}{*}{ Employed } & & 0.109 & 0.048 \\
\hline & & $(0.066)$ & $(0.064)$ \\
\hline \multirow[t]{2}{*}{ Unemployed } & & 0.011 & -0.011 \\
\hline & & $(0.062)$ & $(0.058)$ \\
\hline Inactive & & Baseline & Baseline \\
\hline \multirow[t]{2}{*}{ Strong leader (don't know) } & & -0.467 & -0.234 \\
\hline & & $(0.277)$ & $(0.150)$ \\
\hline \multirow[t]{2}{*}{ Strong leader (very good) } & & $0.678^{* \star \star}$ & $0.607^{* * *}$ \\
\hline & & $(0.159)$ & $(0.061)$ \\
\hline Strong leader (good) & & $0.761^{* * *}$ & $0.706^{* * *}$ \\
\hline
\end{tabular}

(continued) 
Table 20.1 (continued)

\begin{tabular}{|c|c|c|c|}
\hline & (1) & (2) & (3) \\
\hline & Ordered logit & Ordered logit & ML ordered logit \\
\hline \multirow{3}{*}{ Strong leader (bad) } & & $(0.192)$ & $(0.055)$ \\
\hline & & $0.434^{* *}$ & $0.370^{\star * *}$ \\
\hline & & $(0.134)$ & $(0.053)$ \\
\hline Strong leader (very bad) & & Baseline & Baseline \\
\hline \multirow[t]{2}{*}{ Upper class } & & $0.323^{* *}$ & $0.382^{* *}$ \\
\hline & & $(0.117)$ & $(0.128)$ \\
\hline \multirow{2}{*}{ Upper middle } & & $0.297^{*}$ & $0.273^{* * *}$ \\
\hline & & $(0.145)$ & $(0.067)$ \\
\hline \multirow[t]{2}{*}{ Lower middle } & & 0.216 & $0.198^{* * *}$ \\
\hline & & $(0.114)$ & $(0.055)$ \\
\hline \multirow[t]{2}{*}{ Working class } & & -0.064 & -0.049 \\
\hline & & $(0.064)$ & $(0.055)$ \\
\hline Lower class & & Baseline & Baseline \\
\hline \multirow[t]{2}{*}{ Class (don't know) } & & $0.831^{* * *}$ & $0.821^{* * *}$ \\
\hline & & $(0.105)$ & $(0.158)$ \\
\hline \multirow[t]{2}{*}{ Ghana } & $-0.605^{* * *}$ & $-0.672^{* * *}$ & \\
\hline & $(0.046)$ & $(0.044)$ & \\
\hline \multirow[t]{2}{*}{ Nigeria } & -0.028 & $-0.233^{* \star *}$ & \\
\hline & $(0.040)$ & $(0.039)$ & \\
\hline \multirow[t]{2}{*}{ Rwanda } & $0.386^{* * *}$ & $0.275^{* *}$ & \\
\hline & $(0.038)$ & $(0.101)$ & \\
\hline \multirow[t]{2}{*}{ South Africa } & $1.349^{* * *}$ & $1.176^{* * *}$ & \\
\hline & $(0.164)$ & $(0.184)$ & \\
\hline \multirow{3}{*}{$\begin{array}{l}\text { Zimbabwe } \\
\operatorname{var}\left(\mu_{j}\right)\end{array}$} & & Baseline & Baseline \\
\hline & & & $0.738^{* * *}$ \\
\hline & & & $(0.173)$ \\
\hline$N$ & 9827 & 9776 & 9776 \\
\hline No. of regions & - & - & 39 \\
\hline Log-likelihood & $-16,736$ & $-16,417$ & $-16,433$ \\
\hline LR test ( $p$-value) & 0.000 & 0.000 & 0.000 \\
\hline
\end{tabular}

Notes: The dependent variable is the justifiability of accepting a bribe. The variable is on a 10-point Likert scale, where 1 means never justifiable and 10 always justifiable. Robust clustered standard errors in parentheses in Models (1) and (2); ${ }^{*} p<0.05,{ }^{* *} p<0.01,{ }^{* * *} p<0.001$

but not statistically different from that for the baseline, "agree", at the $5 \%$ significant level. Another interesting finding is that people in Rwanda and South Africa are more likely to condone corruption than people in Zimbabwe. As discussed in previous chapters Rwanda and South Africa are 
among the world leaders in terms of shares of women in parliament, yet they still have relatively high levels of corruption, further contradicting the simplistic view that increasing the number of women in parliament will lead to lower corruption levels or more critical attitudes towards corruption.

Results from Model (2), which adds further controls to the estimation, are consistent with previous findings. The coefficients of interests, "disagree" and "strongly disagree", have the expected negative sign and are statistically significant at the $5 \%$ level.

In further analysis, the average marginal effects are obtained. The marginal effect is negative when the "justifiability" level (scale of the dependent variable) is at 2 or above-recalling that 1 means "always justified" and 10 "always unjustified". Based on the marginal effects, respondents who strongly disagreed that men are better politicians than women are about $1.3 \%$ more likely (baseline $=4 \%$ ) to disapprove corruption than those who agree with the statement.

To improve statistical inference, Model (3) includes a region-level mixed effect in the regression model. The log-likelihood of the model improves, suggesting that the model is superior to the one without the mixed effects. Results from the likelihood ratio test also suggest that the model is better than the one without the multilevel feature. Results are very similar to those obtained from Model (2). The estimates are also more precise and statistically significant at the $0.1 \%$ level. The previous findings are robust to unobserved heterogeneity.

Interestingly, results from both Models (2) and (3) suggest that women are equally likely as men to condone corruption, a finding that contradicts the fairer-sex hypothesis proposed by Dollar et al. (2001). This is in line with the previous research by Alhassan-Alolo (2007), who finds that women in public positions in Ghana do not have different ethical principles than their male counterparts and that both sexes are equally likely to act unethically when societal constructs call for it. Similarly, McCabe et al. (2006) show that, in the U.S., "expressive traits and egalitarian genderrole attitudes contribute to both men's and women's propensity to perceive unethical workplace behavior as unethical" (p. 101) rather than gender alone. Goetz (2007) further argues that in a "female-dominant working environment, or where women professionals are dealing with women clients or with a socially inferior class, women professionals are not averse to extorting unofficial 'payments' for services that ought to be provided as a right” (p. 101). Additionally, results from the present study 
suggest that people who agree that men are better political leaders than women are more likely to condone corruption, regardless of gender. This is in line with an essential aspect of patriarchy, a system that can only exist as long as it is reinforced by men and women alike (Enloe 2017). Previous research on the relationship between corruption and political participation, which criticizes the overly naive view by authors such as Dollar et al. (2001), argued that the relationship between gender and corruption is rooted in the fairness of the system (Sung 2003) and in opportunity (Alhassan-Alolo 2007; Bjarnegård 2013), not in gender differences. And while a fairer, more equal system and access to opportunities for all are essential in fighting corruption, the findings in this chapter suggest that in order to change views on corruption, a fairer system that gives opportunities for participation to women (such as in Rwanda) is not enough when underlying power dynamics, that is, patriarchy, are not addressed.

Other authors also hint at the role underlying gender norms might play in the relationship between corruption and gender. Esarey and Chirillo (2013) argue that women's behaviour is marked by societal rules more than by their gender, and therefore, women are much more aware and reluctant to commit acts of corruption when it is systematically seen as immoral. However, if corruption is the modus operandi in the system, they are less likely to abstain from the practice. Echazu (2010) posits that women's behaviour is more honest and reliable probably because they are a minority. This minority bias makes them more aware and sensitive to breaking the rules. So rather than intrinsically being more prone to honesty, it is their current situation that makes them act less corrupt. Alatas et al. (2009) conducted surveys and found that gender differences regarding corruption are not equally present in all societies. They argue that this could be due to "the differing social roles of women across cultures" (Alatas et al. 2009, p. 678). They state that "in relatively more patriarchal societies where women do not play as active a role in the public domain, women's views on social issues may be influenced to a greater extent by men's views. In such societies, one would expect to see less of a gender difference in behavior toward corruption in comparison with societies where women feel more comfortable in voicing their own opinions" (Alatas et al. 2009, p. 678). This view is supported by the present study's findings showing that men's and women's attitudes on corruption and the participation of women are very similar.

Attitudes are not static and are heavily influenced by other factors such as education, which has been included as a control variable. As expected, 
education has a negative effect on attitudes towards corruption in Model (3), consistent with findings from Eicher et al. (2009), although the statistical significance and size of the factor are weaker than what previous research suggested (e.g. Truex 2011). Patriarchy is not a static system and explicitly does not only focus on the domination of men over women but shows a complicated web of power relationships, where "different resources of protection and resistance are available to men and women in different social positions. For women of privilege, class confers power on subordinated women. For more disadvantaged women, subordinated status creates opportunities for resistance" (Hunnicutt 2009, p. 565). Hence, one cannot look at the role of patriarchy without also analysing economic class as an additional layer in this analysis. One may think that a wealthier person may be more likely to benefit from corruption, as they have access to corruption networks or, as Lui (1985) argues, they have higher time costs, which make them more willing to pay a bribe to economize time on the queue. Consistent with the idea that class does shape attitudes towards power, the results show that individuals in the upper class are more likely to condone corruption than individuals in the lower class. Interestingly, the attitudes towards corruption of respondents working in the government or public institutes are not significantly different from those of people working in non-profit organizations. This result is in contrast to what Bardhan (2006) proposes but consistent with the argument that attitudes towards corruption and participation of women are based on underlying societal norms rather than on the workplace.

\section{Conclusion}

This study's findings strongly suggest that patriarchal structures can be linked to views on corruption. While previous research already linked stereotypes about female political candidates and the perception of political corruption (Barnes and Beaulieu 2014; Esarey and Schwindt-Bayer 2018), this study takes it further by connecting attitudes towards women's political leadership with attitudes on corruption. Showing how patriarchy and corruption are connected will help in "exposing ways patriarchal systems are being perpetuated today [and] will enable us to more effectively challenge and dismantle them" (Enloe 2017, p. 17). While corruption, gender equality and women's political participation in particular are all issues worth addressing in their own right, this study shows that changing attitudes towards women in politics, and therefore challenging patriarchal 
structures, can also change attitudes towards corruption and, therefore, is expected to have a multilayered positive effect on development. Findings from the analysis clearly support the hypothesis that patriarchal norms play a role in how one judges corruption.

Findings from this chapter therefore have several implications. Firstly, they suggest that a more bottom-up policy approach is important to successfully change attitudes towards corruption. Rather than relying on the (few) female politicians to break the old boys' network and to fight against corruption, policymakers should also promote the changing of gender norms at the grass-root level and change the climate of corruption through a large-scale socialization process. While the traditional top-down approach has the drawback of relying on the minority in a network to induce changes, which has proven to be difficult, the proposed bottom-up approach tries to transform the social perception from within and avoids counting only on the few. This is more likely to produce a more durable outcome by reducing the risk of reversal due to a sudden drop in the percentage of female politicians in the national parliament or disappointment with women participating in the same corrupt networks.

Secondly, this chapter argues that changing attitudes towards participation of women in all spheres of society will also help change attitudes towards corruption. There is a second benefit to thinking about both issues as a question of patriarchal norms rather than inherent gender differences. Making anti-corruption the standard-bearer of the need for women to join the political sphere can backfire (Alhassan-Alolo 2007). Since women are not necessarily less corrupt, this might hurt not only anti-corruption efforts but also the goal to involve women in politics. Instead, the main argument could be that women diversify the thinking of the government and play a decisive role in the creation of multidimensional politics, which benefits society as a whole (Sung 2006). All in all, women are equally corrupt as men given the opportunity and power structure. To successfully fight against corruption and improve the political participation of women, underlying structures need to be addressed.

\section{REFERENCES}

Alatas, V., Cameron, L., Chaudhuri, A., Erkal, N., \& Gangadharan, L. (2009). Gender, Culture, and Corruption: Insights from an Experimental Analysis. Southern Economic Journal, 75(3), 663-680.

Alhassan-Alolo, N. (2007). Gender and Corruption: Testing the New Consensus. Public Administration and Development, 27(3), 227-237. 
Bardhan, P. (2006). The Economist's Approach to the Problem of Corruption. World Development, 34(2), 341-348.

Barnes, T. D., \& Beaulieu, E. (2014). Gender Stereotypes and Corruption: How Candidates Affect Perceptions of Election Fraud. Politics \& Gender, $10(3), 365-391$.

Bauer, G., \& Burnet, J. E. (2013). Gender Quotas, Democracy, and Women's Representation in Africa: Some Insights from Democratic Botswana and Autocratic Rwanda. Women's Studies International Forum, 41(2), 103-112.

Bjarnegård, E. (2013). Gender, Informal Institutions and Political Recruitment: Explaining Male Dominance in Parliamentary Representation. Basingstoke: Palgrave Macmillan.

Bratton, K. A., \& Ray, L. P. (2002). Descriptive Representation, Policy Outcomes, and Municipal Day-Care Coverage in Norway. American Journal of Political Science, 46(2), 428-437.

Dollar, D., Fisman, R., \& Gatti, R. (2001). Are Women Really the "Fairer" Sex? Corruption and Women in Government. Journal of Economic Behavior es Organization, 46(4), 423-429.

Echazu, L. (2010). Corruption and the Balance of Gender Power. Review of Law \& Economics, 6(1), 59-74.

Eicher, T., García-Peñalosa, C., \& van Ypersele, T. (2009). Education, Corruption, and the Distribution of Income. Journal of Economic Growth, 14(3), 205-231.

Enloe, C. (2017). The Big Push: Exposing and Challenging the Persistence of Patriarchy. Oakland, CA: University of California Press.

Esarey, J., \& Chirillo, G. (2013). "Fairer Sex" or Purity Myth? Corruption, Gender, and Institutional Context. Politics \& Gender, 9(4), 361-389.

Esarey, J., \& Schwindt-Bayer, L. (2018). Women's Representation, Accountability and Corruption in Democracies. British Journal of Political Science, 48(3), 659-690.

Fox, R. L., \& Lawless, J. L. (2004). Entering the Arena? Gender and the Decision to Run for Office. American Journal of Political Science, 48(2), 264-280.

Friedman, E. (2000). Unfinished Transitions: Women and the Gendered Development of Democracy in Venezuela, 1936-1996. University Park, PA: The Pennsylvania State University Press.

Fulton, S. A., Maestas, C. D., Maisel, L. S., \& Stone, W. J. (2006). The Sense of a Woman: Gender, Ambition, and the Decision to Run for Congress. Political Research Quarterly, 59(2), 235-248.

Glick, P., \& Fiske, S. T. (1996). The Ambivalent Sexism Inventory: Differentiating hostile and benevolent sexism. Journal of Personality and Social Psychology, $70(3), 491-512$.

Goetz, A.-M. (2007). Political Cleaners: Women as the New Anti-Corruption Force? Development and Change, 38(1), 87-105.

Goetz, A.-M., \& Hassim, S. (Eds.). (2003). No Shortcuts to Power: African Women in Politics and Policy Making. London: Zed Books. 
Hunnicutt, G. (2009). Varieties of Patriarchy and Violence against Women Resurrecting "Patriarchy" as a Theoretical Tool. Violence Against Women, 15(5), 553-573.

Inglehart, R., Haerpfer, C., Moreno, A., Welzel, C., Kizilova, K., Diez-Medrano, J., Lagos, M., Norris, P., Ponarin, E., Puranen, B., et al. (Eds.). (2014). World Values Survey: Round Six-Country-Pooled Datafile Version. Madrid: JD Systems Institute. Retrieved from http://www.worldvaluessurvey.org/WVS DocumentationWV6.jsp.

King, E. M., \& Mason, A. D. (2001). Engendering Development through Gender Equality in Rights, Resources, and Voice. World Bank Policy Research Report 21776. Washington, DC: World Bank. Retrieved from http://documents. worldbank.org/curated/en/2001/01/891686/engendering-developmentthrough-gender-equality-rights-resources-voice

Kittilson, M. C. (2006). Challenging Parties, Changing Parliaments: Women and Elected Office in Contemporary Western Europe. Columbus, OH: Ohio State University Press.

Lui, F. T. (1985). An Equilibrium Queuing Model of Bribery. Journal of Political Economy, 93(4), 760-781.

Matland, R. E., \& Brown, D. D. (1992). District Magnitude's Effect on Female Representation in U.S. State Legislatures. Legislative Studies Quarterly, 17(4), 469-492.

Matland, R. E., \& Montgomery, K. A. (2003). Women's Access to Political Power in Post-Communist Europe. Oxford: Oxford University Press.

McCabe, A. C., Ingram, R., \& Dato-on, M. C. (2006). The Business of Ethics and Gender. Journal of Business Ethics, 64(2), 101-116.

Mill, J. S. (2015 [1861]). On Liberty, Utilitarianism and Other Essays. Oxford: Oxford University Press.

Norris, P. (1985). Women's Legislative Participation in Western Europe. West European Politics, 8(4), 90-101.

Prince, V. (2005). Sex vs. Gender. International Journal of Transgenderism, $8(4), 29-32$.

Ridgeway, C. L. (1997). Interaction and Conservation of Gender Inequality: Considering Employment. American Sociological Review, 62(2), 218-235.

Rothstein, B. (2011). The Quality of Government: Corruption, Social Trust, and Inequality in International Perspective. Chicago, IL: The University of Chicago Press.

Rothstein, B., \& Teorell, J. (2008). What is Quality of Government? A Theory of Impartial Government Institutions. Governance, 21(2), 165-190.

Rule, W. (1994). Women's Underrepresentation and Electoral Systems. Political Science and Politics, 27(4), 689-692.

Schwindt-Bayer, L. A., \& Mishler, W. (2005). An Integrated Model of Women's Representation. Journal of Politics, 67(2), 407-428. 
Steenbergen, M. R., \& Jones, B. S. (2002). Modeling Multilevel Data Structures. American Journal of Political Science, 46(1), 218-237.

Sung, H.-E. (2003). Fairer Sex or Fairer System? Gender and Corruption Revisited. Social Forces, 82(2), 703-723.

Sung, H.-E. (2006). From Victims to Saviours? Women, Power and Corruption. Current History: A Journal of Contemporary World Affairs, 105, 139-143.

Swamy, A., Knack, S., Lee, Y., \& Azfar, O. (2001). Gender and Corruption. Journal of Development Economics, 64(1), 25-55.

Thomas, S. (2005). Introduction. In S. Thomas \& C. Wilcox (Eds.), Women and Elective Office: Past, Present, and Future (pp. 3-25). Oxford: Oxford University Press.

Transparency International. (n.d.). What is Corruption? Retrieved from https:// www.transparency.org/what-is-corruption

Truex, R. (2011). Corruption, Attitudes, and Education: Survey Evidence from Nepal. World Development, 39(7), 1133-1142.

Waylen, G. (2003). Gender and Transitions: What Do We Know? Democratization, $10(1), 157-178$. 